\title{
COMPARISON BETWEEN THREE METHODS OF MEASURING UNDERWATER ILLUMINATION IN COASTAL WATERS
}

\author{
By L. H. N. CoOper, D.Sc. \\ The Plymouth Laboratory
}

(Text-fig. I)

Two investigations are here combined which developed ad hoc at the end of the Second World War and shortly afterwards. The first compared extinction coefficients of sea water obtained by an aerial photographic method (Moore, I947) with those obtained on water samples in a Pulfrich photometer. The second compared measurements with the Pulfrich photometer with measurements by the late Dr W. R. G. Atkins in the sea with photoelectric cells. The intention was to achieve a correlation between the aerial photographic technique of Moore and the photoelectric cell methods of Atkins and Poole using the Pulfrich photometer as a bridge.

There were faults in the design of both investigations but the repetition by more modern techniques, felt to be desirable, has never been achieved; and now that Dr Atkins has died, it is quite clear it never will be. The results, imperfect though they are, seem to be of sufficient interest to justify publication of the manuscript prepared 13 years ago.

The Zeiss Pulfrich Photometer was used (Kalle, I938; Cooper \& Milne, I938, I939) for measuring extinction coefficients of light in sea waters in which scattering occurs. Results have now been found to be two to five times greater than those obtained by other methods. The discrepancies are due to forward scattering of light and variations in the geometry of the light paths in the several methods (see Appendix, p. 548).

\section{COMPARISON WITH MOORE'S BRIGHTNESS PROFILE METHOD}

Moore (1947) described his method as follows: if a sandy beach is photographed vertically from the air through a colour filter, its apparent brightness is found to vary in a simple way with the depth and clarity of the water over it; if the clarity (or the extinction coefficient) of the water is known, the depth of water can be determined by measuring the relative brightness at different points on a single air photograph. If it is not known, the measurements may be made on a pair of photographs taken simultaneously through two special colour filters; since a relationship between the two extinction coefficients may 
be assumed, depths can be determined from the photographs alone without any other source of information. The method proved highly consistent but during development a cross-check against another device, the Pulfrich photometer, was sought. On nine occasions in August 1945 water sampling was synchronized with the aerial photography. The bays studied are a few miles east of Falmouth. The weather was perfect.

Moore's results (I947, tables 7 and 8 ) have been multiplied by 7.55 to convert to extinction coefficients based on Napierian logarithms and the metre as unit of length.

\section{The instrument}

\section{Experimental}

The method of measurement in the Pulfrich photometer using $25 \mathrm{~cm}$ tubes has been fully described (Cooper \& Milne, 1938), but to obtain significant readings from the English Channel waters tubes $\mathrm{I} .00 \mathrm{~m}$ long and $4.0 \mathrm{~cm}$ internal diameter had to be made.

The Zeiss assembly of eyepiece, spectral filter holders and filters, logarithmic sectors and drums was used without modification. An optical bench to carry the measuring assembly, absorption tubes and the Zeiss lamp-housing in the blacked-out cabin of the motor launch 'Vita' was built to an exacting specification.

Distilled water was prepared at Plymouth and used at sea within a week.

Procedure. Due to slight faults in the hastily made metre tubes, standard Pulfrich procedure was impracticable. One tube filled with distilled water was used as a dummy always, and only on the left-hand side of the instrument. It was marked and set always in the same position. The second tube had to be marked and used similarly on the right-hand side. At the start of the day's work the second tube was also filled with distilled water and matched four times with each spectral filter against the dummy tube. The left-hand drum had to be set at such a reading that the right-hand drum gave a transmission $D$ around $40-50 \%$. Let this right-hand drum reading be $a$.

The right-hand tube was then emptied and twice rinsed with the water to be examined. Next it was filled with the sample taking care that no air bubbles became entrapped. This sample was then matched four times with each spectral filter against the dummy, the adjustment being made with the right-hand drum. Let the mean reading be $b$ which was always greater than $a$.

Then

$$
\mu_{M}=\log \frac{I_{\mathrm{H}_{2} \mathrm{O}}}{I_{S W}}=\log b-\log a .
$$

If an unexpectedly turbid water appeared requiring a right-hand drum reading in excess of 100, the limit of the scale, it was necessary only to reduce the arbitrary left-hand drum reading from $g_{1}$ to $g_{2}$ sufficiently to bring the right-hand drum reading within the range of the scale. The correction term

$$
\log g_{1}-\log g_{2}
$$

had then to be added to obtain $\mu_{M}$.

With these precautions it is believed that the results obtained were little inferior to those that would have been obtained with perfect tubes used in the conventional way. 


\section{Correction term, $\mu_{\lambda, \mathrm{H}_{2} \mathrm{O}}$}

In many marine problems one needs to know how much light of a given colour reaches a given depth. It is immaterial whether the light has been absorbed or scattered by water substance, by materials in solution or materials in suspension. It is a grave disadvantage of all methods which compare a sample of a natural water with pure water that the absorption by water substance is not included. In the middle of the visible spectrum the uncertainty may not be of much consequence, but at the red end it may be important. In the red the assessment of the large correction term is intractable. It is now very clear that laboratory absorptiometers involving comparison with distilled water should never be used where a submarine photometric or brightness profile technique is available and appropriate. None the less a detailed examination of how the correction may be assessed may be helpful.

For monochromatic light

$$
\mu_{\lambda, s W}=\mu_{\lambda, M}+\mu_{\lambda, \mathrm{H}_{2} \mathrm{O}} .
$$

where the symbols and those below have the meaning described in the glossary of terms (p. 550). Since the spectral filters select a wave-band between wave-lengths $\lambda_{1}$ and $\lambda_{2}$, a mean correction factor $\mu_{\text {mean }} \lambda_{, H_{2} \mathrm{O}}$ is needed. It depends on the length of the absorption tube and may be computed by the formula of Cooper \& Milne (I939):

$$
\mu_{\text {mean } \lambda, \mathrm{H}_{2} \mathrm{O}}=2.303 \log _{10} \frac{\int_{\lambda_{1}}^{\lambda_{2}} c_{\lambda} \mathscr{F}_{\lambda} V_{\lambda} d \lambda}{\int_{\lambda_{1}}^{\lambda_{2}} c_{\lambda} \mathcal{F}_{\lambda} V_{\lambda} \exp \left(\mu_{\lambda} l\right) d \lambda}
$$

For $\mathcal{F}_{\lambda}$ the monochromatic extinction coefficients determined for pure water by James with Birge (1938) were used and the two integrals evaluated graphically, in order to determine $\mu_{\text {mean }} \lambda, \mathrm{H}_{2} \mathrm{O}$ :

$\begin{array}{ccccccccc}\begin{array}{c}\text { Length of } \\ \text { absorption } \\ \text { tube }\end{array} & \mathrm{S}_{43} & \mathrm{~S}_{47} & \mathrm{~S}_{50} & \mathrm{~S}_{53} & \mathrm{~S}_{57} & \mathrm{~S}_{61} & \mathrm{~S}_{66} & \mathrm{~S}_{72} \\ \mathrm{I} \mathrm{m} & 0.008 & 0.006 & 0.007 & 0.025 & 0.078 & 0.28 & 0.4 \mathrm{I} & \mathrm{I} \cdot 58 \\ 25 \mathrm{~cm} & 0.008 & 0.006 & 0.007 & 0.025 & 0.078 & 0.27 & 0.4 \mathrm{I} & \mathrm{I} \cdot 63\end{array}$

For the filters $\mathrm{S}_{43}-\mathrm{S} 6 \mathrm{I}$ the accuracy of these correction terms is better than the experimental error. For the red filters, due to the characteristics of the photometer lamp, the spectral filters and the human eye, the error of the correction term is greater and its order of magnitude may be computed. Thus for coastal sea water, such as that examined in this work, the standard error of measurement with the red S66 filter amounts to about 0.005-0.0I and with the deep red $\mathrm{S}_{72}$ to $0.02-0.09$.

Sampling at sea. At Portscatho on 2 August distances of the launch from shore were established by Army shore surveyors. On other occasions distances were estimated by eye and later checked from Moore's aerial photographs. Bottom depths are accurate to \pm 3 in. Tide is given as local high water. All samples were taken with a $I \cdot 71$. Nansen-Pettersson water-bottle hauled by hand. Usually samples were run into the absorption tube and examined at once but some had to be stored in glass vessels for as much as $3 \mathrm{~h}$. These were well swirled but not shaken before transfer. Measurements were made as quickly as possible ending always with a repeat with the first filter used. Station data are set out in Table I. 


\section{Comparison of extinction coefficients determined at Portscatho}

In Table 2 will be found extinction coefficients $\mu_{M}$ measured against distilled water. To obtain the extinction coefficients for sea water $\mu_{S W}$, found with each Pulfrich filter, the coefficients for distilled water $\mu_{\mathrm{H}_{2} \mathrm{O}}$ given at the foot of Table 2 have to be added as a correction term. Moore used coefficients corrected in this way by the writer.

It is debatable at what stage the distilled water correction is best applied. The writer now prefers to apply it after the transformation of the Pulfrich results $\mu_{M}$ in terms of Moore's Wratten filters. Moore (I947, table 3) for a number of wave-lengths gives the product $Z_{\lambda} Y_{\lambda}$ of the relative sensitivity of Kodak aero Super XX film to mean noon sunlight $Y_{\lambda}$ and the transmission of the Wratten filters $Z_{\lambda}$. This serves the same purpose as the expression $c_{\lambda} \mathfrak{F}_{\lambda} V_{\lambda}$ of Cooper \& Milne (I939, p. 292) (see glossary of terms).

\section{TABLE 1. STATION DATA}

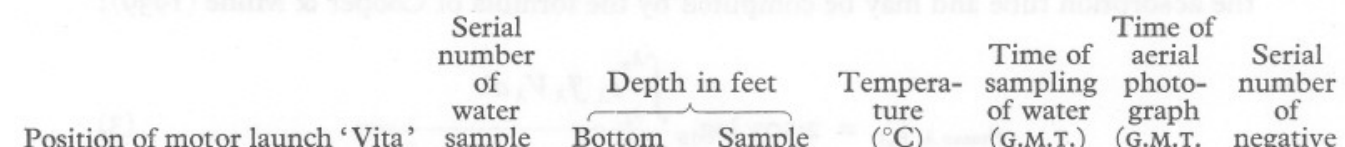

Series 2. Portscatho. 2 August 1945. Flat calm. Local high water II.36 h G.M.T.

\begin{tabular}{|c|c|c|c|c|c|c|c|}
\hline $\begin{array}{l}\text { Anchored } 675 \mathrm{ft} \text {. from sea } \\
\text { wall (fixed by shore } \\
\text { surveyors) }\end{array}$ & $\begin{array}{l}3 \\
4\end{array}$ & $\begin{array}{l}16 \frac{3}{4} \\
16 \frac{3}{4}\end{array}$ & $\begin{array}{r}1 \\
15\end{array}$ & $\begin{array}{l}17 \cdot 73 \\
16 \cdot 38\end{array}$ & $\begin{array}{l}\text { I4.13 } \\
\text { I4.45 }\end{array}$ & $\stackrel{14.44}{-}$ & $\stackrel{0900}{-}$ \\
\hline $\begin{array}{l}\text { Anchored } 3070 \mathrm{ft} \text {. from sea } \\
\text { wall (fixed by shore } \\
\text { surveyors) }\end{array}$ & $\begin{array}{l}5 \\
6 \\
7\end{array}$ & $\begin{array}{l}78 \\
78 \\
78\end{array}$ & $\begin{array}{r}I \\
25 \\
70\end{array}$ & $\begin{array}{l}16 \cdot 83 \\
16 \cdot 30 \\
15 \cdot 17\end{array}$ & $\begin{array}{l}\text { IO. } 23 \\
\text { II. I } 4 \\
\text { IO.56 }\end{array}$ & $\begin{array}{l}10.29 \\
-\end{array}$ & $\stackrel{\text { O801 }}{-}$ \\
\hline $\begin{array}{l}\text { Return visit to } 3070 \mathrm{ft} \text {. } \\
\text { station }\end{array}$ & $\begin{array}{r}8 \\
9 \\
10\end{array}$ & $\overline{-}$ & $\begin{array}{l}15 \\
20 \\
25\end{array}$ & $\begin{array}{l}16 \cdot 31 \\
16 \cdot 12 \\
15 \cdot 90\end{array}$ & $\begin{array}{l}15.53 \\
15.44 \\
\text { I5.32 }\end{array}$ & Z & $\overline{-}$ \\
\hline
\end{tabular}

Series 3. Porth Farm. 3 August 1945. Flat calm. Local high water 12.49 h G.M.T.

Anchored $300 \mathrm{ft}$. estimated

from shore and $50 \mathrm{ft}$. east

II

$9 \frac{1}{6}$

$4 \quad \mathrm{I} 6 \cdot 40$

09.52

09.50

II 34 of surveyed line

Anchored on survey line

$\begin{array}{llrrrrr}\text { I2 } & 28 & \text { I } & 17.3 & \text { II.16 } & \text { II.07 } & \text { II } 70 \\ \text { I3 } & 28 & \text { 10 } & - & \text { II.04 } & - & - \\ \text { I4 } & 28 & 25 & - & 10.47 & - & -\end{array}$

Series 4. Portscatho. 3 August I945. Flat calm. Local high water I2.49 h G.M.T.

Anchored on surveyed line. Position shown by Moore (1947, plates II and I2)

I5
16
I7
18
I9
20
21
22

56
56
56
56
56
$2 \frac{1}{2}$
6
8

$\begin{array}{cc}\text { I } & 18.09 \\ \text { I } & 18.82 \\ 5 & 16.79 \\ 19 & 16.08 \\ 25 & 16.08 \\ \text { I } & - \\ 2 \frac{1}{2} & - \\ 3 \frac{1}{4} & -\end{array}$

13.48

I5.04

I 4.33

I 4.20

I3.29

-

14.20
14.21

I4.23

I 5.40

Tide falling rapidly.

Depth under 'Vita' $7 \frac{1}{2} \mathrm{ft}$.

at $\mathrm{I} 5.35 \mathrm{~h}, 5 \mathrm{ft}$. $10 \mathrm{in}$. at

I6.2I h. All samples taken

from dinghy 
The calculation consists of two parts: first, to compute the extinction coefficient $\mu_{M}$ which would be observed in our modified Pulfrich photometer if ( $a$ ) the Zeiss spectral filters were replaced by the Wratten filters used in the aerial camera and if $(b)$ the electric lamp were replaced by mean noon sunlight; secondly, to compute the correction which such a combination would need for the absorption by water substance in the twin tube.

Inspection of the appropriate $c_{\lambda} \mathcal{F}_{\lambda} V_{\lambda}$ and $Z_{\lambda} Y_{\lambda}$ curves suggested that the extinction coefficient $\mu_{M}$ appropriate for the Wratten green filter with mean noon sunlight could be built up from the Pulfrich $\mu_{M}$ measurements as $\frac{1}{2}\left(\frac{2}{3} \mu_{\mathrm{S} 50}+\mu_{\mathrm{S} 53}+\frac{1}{3} \mu_{\mathrm{S} 57}\right)$ where $\mu_{\mathrm{S} 50}$, etc., represent the extinction coefficients measured with the Zeiss Pulfrich $\mathrm{S}_{5} 0$ filter, etc. Since the simple arithmetic mean, $\frac{1}{3}\left(\mu_{\mathrm{S} 50}+\mu_{\mathrm{S} 53}+\mu_{\mathrm{S} 57}\right)$, differed only slightly from this (mean difference 0.004 , maximum differences 0.014 and 0.009 on determinations exceeding 0.27 ) a more exact but very tedious calculation was not justified.

TABLE 2. MEASURED EXTINCTION COEFFICIENTS $\left(\mu_{M}\right)$ WITH PULFRICH PHOTOMETER IN $1 \mathrm{M}$ TUBES

\begin{tabular}{|c|c|c|c|c|c|c|c|c|c|}
\hline \multirow{2}{*}{$\begin{array}{c}\text { Serial } \\
\text { number } \\
\text { of } \\
\text { water } \\
\text { sample }\end{array}$} & \multirow[b]{2}{*}{$\begin{array}{l}\text { Depth } \\
\text { sampled } \\
\text { in } \\
\text { feet }\end{array}$} & \multicolumn{8}{|c|}{ Measured extinction coefficient $\mu_{M}$ with Pulfrich spectral filter number } \\
\hline & & $\begin{array}{c}\mathrm{S}_{43} \\
\text { violet }\end{array}$ & $\begin{array}{r}\mathrm{S} 47 \\
\text { blue }\end{array}$ & $\begin{array}{l}\text { S } 50 \\
\text { blue- } \\
\text { green }\end{array}$ & $\begin{array}{l}\text { S } 53 \\
\text { green }\end{array}$ & $\begin{array}{l}\mathrm{S} 57 \\
\text { yellow }\end{array}$ & $\begin{array}{l}\text { S6I } \\
\text { orange- } \\
\text { red }\end{array}$ & $\begin{array}{l}\text { S66 } \\
\text { red }\end{array}$ & $\begin{array}{l}\mathrm{S}_{72} \\
\text { deep } \\
\text { red }\end{array}$ \\
\hline \multicolumn{10}{|c|}{ Series 2. Portscatho. 2 August } \\
\hline $\begin{array}{l}3 \\
4\end{array}$ & $\begin{array}{r}1 \\
15\end{array}$ & $\begin{array}{l}0.50 \\
0.59\end{array}$ & $\begin{array}{l}0.40 \\
0.55\end{array}$ & $\begin{array}{l}0.39 \\
0.45\end{array}$ & $\begin{array}{l}0.29 \\
0.43\end{array}$ & $\begin{array}{l}0.29 \\
0.35\end{array}$ & $\begin{array}{l}0.27 \\
0.36\end{array}$ & $\begin{array}{l}0.23 \\
0.35\end{array}$ & $\begin{array}{l}0.23 \\
0.31\end{array}$ \\
\hline $\begin{array}{l}5 \\
6 \\
7\end{array}$ & $\begin{array}{r}1 \\
25 \\
70\end{array}$ & $\begin{array}{l}0.38 \\
I \cdot 10 \\
0.83\end{array}$ & $\begin{array}{l}0.33 \\
0.91 \\
0.74\end{array}$ & $\begin{array}{l}0.31 \\
0.76 \\
0.67\end{array}$ & $\begin{array}{l}0.26 \\
0.58 \\
0.64\end{array}$ & $\begin{array}{l}0.25 \\
0.56 \\
0.60\end{array}$ & $\begin{array}{l}0.24 \\
0.54 \\
0.57\end{array}$ & $\begin{array}{l}0.21 \\
0.53 \\
0.58\end{array}$ & $\begin{array}{l}0.19 \\
0.55 \\
0.54\end{array}$ \\
\hline $\begin{array}{r}8 \\
9 \\
\text { 10 }\end{array}$ & $\begin{array}{l}15 \\
20 \\
25\end{array}$ & $\begin{array}{l}0.40 \\
0.53 \\
-\end{array}$ & $\begin{array}{l}0.37 \\
0.46 \\
0.43\end{array}$ & $\frac{0.35}{-}$ & $\begin{array}{l}0.29 \\
0.40 \\
0.37\end{array}$ & $\frac{0.32}{-}$ & $\begin{array}{l}0.30= \\
0.39 \\
0.35\end{array}$ & $\begin{array}{c}0.29 \\
-\end{array}$ & $\begin{array}{c}0.26 \\
-\end{array}$ \\
\hline \multicolumn{10}{|c|}{ Series 3. Porth Farm. 3 August } \\
\hline II & 4 & 0.49 & 0.39 & 0.30 & 0.30 & 0.25 & $0 \cdot 24$ & 0.25 & 0.25 \\
\hline 12 & I & 0.48 & 0.36 & 0.30 & 0.30 & 0.24 & 0.26 & 0.24 & 0.21 \\
\hline I3 & Io & 0.40 & 0.35 & 0.27 & 0.27 & 0.24 & 0.25 & 0.21 & 0.24 \\
\hline 14 & 25 & 0.43 & 0.36 & 0.30 & 0.31 & 0.30 & 0.28 & 0.24 & 0.20 \\
\hline \multicolumn{10}{|c|}{ Series 4. Portscatho. 3 August } \\
\hline $\begin{array}{l}\text { I5 } \\
\text { 16 }\end{array}$ & I & $0.3 I$ & 0.29 & $0 \cdot 24$ & 0.24 & 0.23 & 0.21 & 0.21 & 0.15 \\
\hline $\begin{array}{l}\text { I6 } \\
\text { I7 }\end{array}$ & I & 0.46 & 0.31 & 0.22 & 0.23 & 0.21 & 0.23 & 0.20 & 0.16 \\
\hline $\begin{array}{l}\text { I7 } \\
\text { I8 }\end{array}$ & 5 & - & 0.29 & - & 0.26 & - & 0.27 & - & $\overline{0.26}$ \\
\hline $\begin{array}{l}18 \\
19\end{array}$ & $\begin{array}{l}19 \\
25\end{array}$ & $\overline{0.39}$ & $\begin{array}{l}0.35 \\
0.38\end{array}$ & $\overline{0.31}$ & $\begin{array}{l}0.33 \\
0.32\end{array}$ & $\overline{0.27}$ & $\begin{array}{l}0.32 \\
0.32\end{array}$ & $\overline{0.31}$ & $\begin{array}{l}0.26 \\
0.29\end{array}$ \\
\hline 20 & I & $I \cdot 00$ & 0.87 & $0.8 \mathrm{I}$ & 0.77 & 0.74 & 0.70 & 0.62 & 0.64 \\
\hline $2 I$ & $2 \frac{1}{2}$ & 0.51 & $0.4 \mathrm{I}$ & 0.34 & 0.31 & 0.31 & 0.26 & 0.38 & - \\
\hline 22 & $3 \frac{1}{4}$ & 0.51 & 0.46 & 0.36 & 0.37 & 0.34 & 0.32 & 0.26 & - \\
\hline \multirow{2}{*}{\multicolumn{10}{|c|}{$\begin{array}{l}\text { To obtain extinc- } \\
\text { tion coefficient in } \\
\text { sea water } \mu_{\mathrm{SW}} \text { add } \\
\mu_{\mathrm{H}_{2} \mathrm{O}}=\end{array}$}} \\
\hline & & $0.00_{8}$ & $0.00_{6}$ & $0.00_{7}$ & $0.02_{4}$ & 0.078 & $0.28_{0}$ & $0.4 \mathrm{I}$ & $\mathrm{I} \cdot 58$ \\
\hline
\end{tabular}


At intervals of $20 \mathrm{~m} \mu$ the product of $Z_{\lambda} Y_{\lambda}$ (see above) and $\mu_{\mathrm{H}_{2} \mathrm{O}}$ for monochromatic light as given by James with Birge (1938) was evaluated. Integration gives the extinction coefficients of pure water $\mu_{\mathrm{H}_{2} \mathrm{O}}$ which would occur in the modified Pulfrich photometer equipped with the Wratten filters in mean noon sunlight. The correction term is 0.05 for the Wratten green filter and 0.29 for the Wratten red filter.

\section{TABLE 3. EXTINCTION COEFFICIENTS FOR GREEN AND RED LIGHT DETERMINED WITH WRATTEN FILTERS}

(a) Cross-computed from measurements (Table 2) with the spectral filters of the Pulfrich photometer and corrected for absorption by water substance (columns 3 and 4 ).

(b) Determined directly by the brightness profile method (columns 7 and 8).

(c) Ratios between extinction coefficient determined by the Pulfrich photometer and by the brightness profile method (columns 9 and ro).

Determinations based on the Pulfrich photometer

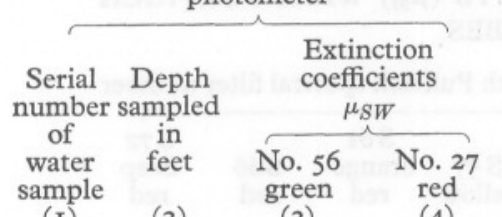

Determinations based on brightness

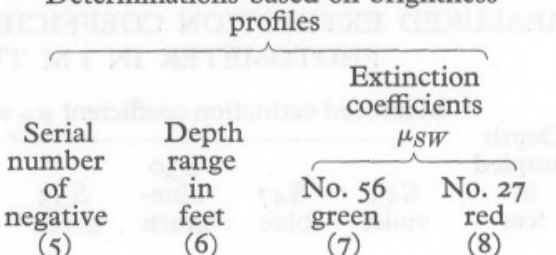

Series 2. Portscatho. 2 August

\begin{tabular}{|c|c|}
\hline \multicolumn{2}{|c|}{$\begin{array}{l}\text { Ratio of } \\
\text { coefficients }\end{array}$} \\
\hline col. 3 & col. 4 \\
\hline col. 7 & col. 8 \\
\hline $\begin{array}{l}\text { No. } 56 \\
\text { green } \\
\text { (9) }\end{array}$ & $\begin{array}{c}\text { No. } 27 \\
\text { red } \\
\text { (10) }\end{array}$ \\
\hline
\end{tabular}

$\begin{array}{crrr}3 & \text { I } & 0.37 & \\ 4 & \text { I5 } & 0.47 & \\ \text { Mean } & & 0.42 & \\ 5 & \text { I } & 0.32 & 0.5 \\ 6 & 25 & 0.68 & 0.8 \\ 7 & 70 & 0.69 & 0.8\end{array}$

$\begin{array}{ll}0.54 & -54 \\ 0.64 & -\end{array}$

0.59

$0.4 \mathrm{I}$

0.83

0.86

Series 3. Porth Farm. 3 August

$\begin{array}{lcc}\text { II } & 4 & 0.34 \\ \text { I2 } & \text { I } & 0.34 \\ \text { I3 } & \text { IO } & 0.3 \text { I } \\ \text { I4 } & \text { 25 } & 0.35 \\ \text { Mean of } & \text { I2-I4 } & 0.33\end{array}$

\begin{tabular}{|c|c|}
\hline I5 & I \\
\hline I6 & I \\
\hline I7 & 5 \\
\hline I8 & I9 \\
\hline 19 & 25 \\
\hline \multicolumn{2}{|c|}{ Weighted mean } \\
\hline 20 & I \\
\hline $2 \mathrm{I}$ & $2 \frac{1}{2}$ \\
\hline 22 & $3 \frac{1}{4}$ \\
\hline \multicolumn{2}{|c|}{$\begin{array}{l}\text { Mean of } 21 \\
\text { and } 22\end{array}$} \\
\hline
\end{tabular}

Series 4. Portscatho. 3 August
0.17

-

0.39
-
-
0.41
I.9

$\begin{array}{ll}\text { - } & - \\ \text { I.8 } & \text { I.3 }\end{array}$

\begin{tabular}{|c|c|c|c|c|c|c|}
\hline 0.50 & - & - & - & - & - & - \\
\hline $0.5 \mathrm{I}$ & - & - & - & - & - & - \\
\hline 0.55 & 975 & $4-24$ & 0.18 & 0.40 & - & - \\
\hline $0.6 \mathrm{I}$ & 976 & $2-12$ & 0.20 & 0.42 & - & - \\
\hline 0.60 & 979 & $2-16$ & 0.16 & 0.39 & - & - \\
\hline 0.56 & Mean & & 0.18 & 0.40 & I. 8 & I. 4 \\
\hline 0.95 & - & - & - & - & - & - \\
\hline 0.56 & 1008 & $4-18$ & 0.25 & 0.48 & - & - \\
\hline 0.58 & IOI 2 & 2-16 & 0.20 & 0.42 & - & - \\
\hline \multirow[t]{2}{*}{0.57} & Mean & & 0.23 & 0.45 & I. 7 & I. 3 \\
\hline & & & Mear & & I. 8 & I'3 \\
\hline
\end{tabular}


Addition of these two quantities gives the extinction coefficient $\mu_{S W}$ which should be measured by an instrument of our modified Pulfrich type lit by mean noon sunlight, using the Wratten filter in question and replacing the eye by the aerial camera and its photographic film (Table 3 , columns 3 and 4).

Results of the two methods of measurement are compared in Table 3, the gist of which lies in columns 9 and ro giving the ratios of $(a)$ extinction coefficients for mean noon sunlight transmitted by the Wratten filters and recorded by the photographic film as estimated from the Pulfrich measurements to $(b)$ coefficients determined directly by the brightness profile method. The ratios are variable, considerably exceed unity and are larger for the green $(\cong I \cdot 8)$ than for the red filter $(\cong I \cdot 3)$. The explanation in terms of forward scattering (Atkins \& Poole, I952) and the geometrical optics of the Pulfrich system has now become clear (see Appendix).

\section{COMPARISON WITH POOLE AND ATKINS'S SUBMARINE PHOTOELECTRIC METHOD}

In the English Channel or Plymouth Sound in 1946 Dr W. R. G. Atkins on boad R.V. 'Sabella', immediately before or after his submarine photoelectric measurements, took water samples with the Nansen-Pettersson water-bottle. These were brought back to the laboratory in hydrographic green-glass sample-bottles, about six being needed for one examination. The same night they were examined in the Pulfrich assembly that had been used off Falmouth in 1945 (Table 4 , in which the distilled water correction $\mu_{\mathrm{H}_{2} \mathrm{O}}$ has been added to the extinction coefficients measured, $\mu_{M}$, to convert them to a basis applicable in the sea, namely $\mu_{S W, P}$ ).

The Corning blue filter used by Atkins has maximum transmission at about $430 \mathrm{~m} \mu$ so that results with it are best compared with the Pulfrich violet filter $\mathrm{S}_{43}$, maximum transmission at $434 \mathrm{~m} \mu$.

The BG 2 filter, also blue, has maximum transmission at $450 \mathrm{~m} \mu$ and has been compared with the mean of the coefficients found with the Pulfrich filters $\mathrm{S}_{43}(434 \mathrm{~m} \mu)$ and $\mathrm{S}_{47}(463 \mathrm{~m} \mu)$.

The Corning green and VG9 submarine filters and the Pulfrich $\mathrm{S}_{53}$ filter all have maximum transmission close to $530 \mathrm{~m} \mu$ and admit of straightforward comparison.

The combination $\mathrm{OG}_{2}+\mathrm{VG}_{9}$ has a maximum transmission close to that of the yellow $\mathrm{S}_{57}$ filter.

All the red filters have a sharp cut-off in transmission on the side of shorter wave-length but high transmission extends into the infra-red. In the red the extinction coefficient of water substance increases rapidly with wavelength whilst the sensitivity of the human eye and of the several photocells decreases. The Weston selenium cell becomes insensitive above $680 \mathrm{~m} \mu$. Moreover the composition of red light in the sea changes very rapidly with depth. The very tedious calculations necessary to allow accurately for these 
conflicting sources of error have not been attempted. It has been considered sufficient to compare the submarine measurements made with filter RG I with Pulfrich filter S6I and those with the Corning red and RG 5 filters with Pulfrich filter S66.

\section{Station data}

I2 fuly 1946. Station in English Channel, 2 miles east of the Eddystone ( $50^{\circ} \mathrm{II}^{\prime} \mathrm{N}$, $4^{\circ} \mathrm{I} 3^{\prime} \mathrm{W}$.). Clear sun. Cubical submarine photometer. The two methods agree that transparency decreased with depth but do not agree in detail. Whereas for both blue and green light the Pulfrich method showed the maximum decrease in transparency between 20 and $25 \mathrm{~m}$ (Table 4), the cubical photometer showed it between 15 and $20 \mathrm{~m}$. The observations on this date are the most satisfactory for purposes of comparison and most weight should be set on them.

26 August 1946. International Hydrographic Station E I ( $50^{\circ} 04^{\prime}$ N., $4^{\circ} 22^{\prime}$ W.). On this occasion the most complete set of submarine photometric measurements are available. Between noon and $15.30 \mathrm{~h}$ five different filter combinations were used with the Weston selenium cell which has maximum sensitivity at $580 \mathrm{~m} \mu$ and is insensitive above $680 \mathrm{~m} \mu$. At $15.45 \mathrm{~h}$ water samples for Pulfrich examination were drawn from three depths only, namely 0,5 and $50 \mathrm{~m}$. From Table 4 it will be seen that the Pulfrich extinction coefficients on surface water were $0.07-0.14$ greater than those at

TABLE 4. EXTINCTION COEFFICIENTS $\left(\mu_{S W, P}\right)$ IN WATER FROM THE ENGLISH CHANNEL NEAR PLYMOUTH MEASURED WITH THE PULFRICH PHOTOMETER.

Distilled water correction applied.

\begin{tabular}{|c|c|c|c|c|c|c|c|c|c|}
\hline \multirow{2}{*}{$\begin{array}{c}\text { Depth } \\
(\mathrm{m})\end{array}$} & \multirow{2}{*}{$\begin{array}{l}\text { Temp. } \\
\left({ }^{\circ} \mathrm{C}\right)\end{array}$} & \multicolumn{8}{|c|}{ Spectral filter } \\
\hline & & $\mathrm{S}_{43}$ & $\mathrm{~S}_{47}$ & $\begin{array}{l}\mathrm{S}_{50} \\
\mathrm{I}_{2} \mathrm{~J}\end{array}$ & $\begin{array}{l}\mathrm{S}_{53} \\
\mathrm{I946}\end{array}$ & $S_{57}$ & S6I & S66 & $\mathrm{S}_{72}$ \\
\hline 0 & I9.45 & 0.249 & $0.2 \mathrm{I}_{3}$ & $0.18_{3}$ & $0.18_{8}$ & $0.22_{2}$ & 0.437 & 0.555 & $I \cdot 76_{6}$ \\
\hline 5 & 15.00 & $0.22_{9}$ & $0.2 \mathrm{I}_{3}$ & $0.2 \mathrm{O}_{2}$ & $0.19_{3}$ & $0.24_{1}$ & 0.437 & 0.540 & $\mathrm{I} \cdot 78_{6}^{\circ}$ \\
\hline Io & 13.93 & 0.253 & $0.22_{6}$ & 0.199 & $0.20_{5}$ & $0.24_{5}$ & $0.46_{0}$ & $0.56_{3}$ & $I \cdot 78_{9}$ \\
\hline 15 & 13.52 & $0.3 I_{5}$ & $0.24_{4}$ & $0.22_{1}$ & $0.20_{8}$ & $0.26_{2}$ & $0.44_{6}$ & $0.56_{3}$ & $1 \cdot 77_{0}$ \\
\hline 20 & $13.4 \mathrm{I}$ & $0.30_{0}$ & 0.258 & $0.2 \mathrm{I}_{6}$ & $0.2 \mathrm{I}_{0}$ & $0.25_{2}$ & $0.47_{0}$ & 0.573 & I. 75 , \\
\hline 25 & $12 \cdot 94$ & $0.4 \mathrm{I}_{6}$ & 0.354 & $0.3 \mathrm{I}_{7}$ & $0.28_{8}$ & $0.3 I_{2}$ & $0.5 I_{0}$ & $0.6 \mathrm{I}_{5}$ & $\mathrm{I} \cdot 8 \mathrm{I}_{0}$ \\
\hline \multicolumn{10}{|c|}{26 August I946 } \\
\hline 0 & - & $0.92_{6}$ & $0.83_{1}$ & 0.797 & $0.75_{4}$ & $0.80_{5}$ & $\mathrm{I} \cdot \mathrm{OO}_{2}$ & $I \cdot I_{3}$ & $2 \cdot 3 I_{5}$ \\
\hline 5 & - & $0.83_{2}$ & 0.750 & $0.72_{8}$ & $0.70_{8}$ & $0.7 \mathrm{I}_{9}$ & $0.86_{0}$ & $\mathrm{I} \cdot \mathrm{O}_{3}$ & $2 \cdot 151$ \\
\hline 50 & - & $0.82_{6}$ & $0.72_{0}$ & $0.68_{9}$ & $0.70_{8}$ & $0.70_{4}$ & $0.87_{6}$ & 0.998 & $2 \cdot 153$ \\
\hline \multicolumn{10}{|c|}{24 October I946 } \\
\hline 0 & $\mathrm{I} 4.0$ & $0.78_{9}$ & $0.70_{0}$ & $0.67_{3}$ & $0.58_{4}$ & $0.56_{3}$ & 0.737 & 0.844 & I.99 \\
\hline 5 & I $4 \cdot \mathrm{I}$ & $0.69_{8}$ & $0.69_{5}$ & $0.60_{3}$ & 0.558 & 0.547 & $0.72_{2}$ & $0.82_{5}$ & I. 95 \\
\hline IO & $\mathrm{I} 4 \cdot 2$ & $0.68_{4}$ & $0.63_{1}$ & 0.546 & $0.50_{3}$ & 0.532 & $0.70_{1}$ & 0.796 & I.95 \\
\hline 15 & $\mathrm{I} 4 \cdot 2$ & $0.70_{8}$ & 0.658 & $0.56_{3}$ & $0.48_{8}$ & $0.52_{5}$ & $0.70_{0}$ & $0.8 \mathrm{I}_{5}$ & I.97 \\
\hline \multicolumn{10}{|c|}{30 October $1946, \mathrm{I} 4.40 \mathrm{~h}$} \\
\hline 0 & - & $I \cdot 45_{4}$ & $I \cdot 26_{4}$ & $\mathrm{I} \cdot 08_{2}$ & $0.98_{5}$ & $0.96_{6}$ & $\mathrm{I} \cdot \mathrm{O}_{37}$ & $\mathrm{I} \cdot \mathrm{IO}_{8}$ & $2 \cdot 257$ \\
\hline 5 & - & $I \cdot 4 I_{7}$ & $I \cdot 27_{2}$ & $I \cdot I 3_{8}$ & $\mathrm{I} \cdot \mathrm{OI}_{7}$ & $\mathrm{I} \cdot \mathrm{OO}_{5}$ & $I \cdot I O_{0}$ & $\mathrm{I} \cdot 2 \mathrm{I}_{4}$ & $2 \cdot 30_{9}$ \\
\hline \multicolumn{10}{|c|}{6 November 1946} \\
\hline 0 & 13.68 & 0.174 & $0 . \mathrm{I}_{53}$ & 0.141 & $0.12_{8}$ & 0.148 & 0.342 & 0.470 & $\mathrm{I} \cdot 6 \mathrm{I}_{0}$ \\
\hline 5 & I3.68 & $0.37_{4}$ & $0.37_{3}$ & $0.34_{6}$ & $0.33_{0}$ & 0.330 & $0.53_{4}$ & $0.62_{7}$ & $\mathrm{I} \cdot 78_{1}$ \\
\hline 25 & I3.68 & $0.24_{1}$ & $0.23_{1}$ & $0.18_{8}$ & $0.18_{2}$ & $0.22_{7}$ & $0.4 \mathrm{I}_{4}$ & $0.52_{2}$ & $\mathrm{I} \cdot 69_{5}$ \\
\hline 50 & 13.68 & $0.39_{6}$ & $0.38_{3}$ & $0.35_{4}$ & 0.333 & 0.339 & $0.5 I_{8}$ & $0.6 \mathrm{I}_{5}$ & $\mathrm{I} \cdot 78_{3}$ \\
\hline 70 & 13.68 & $0.38_{2}$ & $0.36_{9}$ & 0.359 & $0.29_{8}$ & $0.3 \mathrm{I}_{1}$ & $0.5 I_{2}$ & $0.6 \mathrm{I}_{6}$ & $I \cdot 76_{5}$ \\
\hline
\end{tabular}


5 and $50 \mathrm{~m}$. Surface samples are often more turbid than the waters beneath while phosphate analyses there are often anomalous. It is not known how thick this more turbid surface rind of water was, probably it did not exceed I m. Consequently the surface Pulfrich measurements cannot be compared with any submarine photometric measurements. For the upper waters only a single set of figures at $5 \mathrm{~m}$ is available for calculation of ratios and the excellent set of submarine measurements loses some of its value.

On the surface sample the effect upon settling of suspended matter of time of standing in the Pulfrich absorption tube was measured. The sample was collected at $15.45 \mathrm{~h}$, transferred to the absorption tube and examined by Dr Atkins at $21.10 \mathrm{~h}$ for the extinction coefficient as measured, $\mu_{M}$. Subsequent measurements were made as shown in Table 5 .

\section{TABLE 5. CHANGES IN EXTINCTION COEFFICIENTS $\left(\mu_{M}\right)$ ON STANDING}

$\begin{array}{lccc}\text { Water from o m depth, 26 August. } & & \\ \text { Treatment } & \text { Vilet } & \text { Blue } & \text { Deep Red } \\ \text { Silter } & \mathrm{S}_{72} \\ \text { Water freshly transferred to tube at 21.ro h } & 0.92 & 0.83 & 0.73 \\ \begin{array}{c}\text { Following morning after standing in tube } \\ \text { overnight undisturbed }\end{array} & 0.7 \mathrm{I} & - & 0.55 \\ \begin{array}{c}\text { After shaking up in the tube but without } \\ \text { creating air bubbles }\end{array} & 0.86 & 0.76 & 0.65\end{array}$

These results show the need for speed once the sea water has been transferred to the absorption tube. They also reveal some physical agency in the uppermost metre of water opposing the tendency of light-scattering particles to sink.

24 October 1946. Coastal water off Wembury in $33 \mathrm{~m}$ depth, $50^{\circ} 17^{\prime} \mathrm{N} ., 4^{\circ} \mathrm{o} 5^{\prime} \mathrm{W}$. Afternoon, photometer not now known. The water here was more turbid than in the open Channel, being most so near the surface (Table 4). Mean values have been evaluated by both methods for the stratum between the surface and $15 \mathrm{~m}$ depth.

30 October 1946. Moored to no. 3 buoy inside east end of Plymouth Breakwater. Depth II m. Grey cloud Io/10. Samples for Pulfrich measurements were taken first at $\mathrm{II} .35 \mathrm{~h}$ and again at $\mathrm{I} 4.40 \mathrm{~h}$ when the turbidity was found to have increased considerably. Measurements with the submarine photometer were made between $\mathrm{I} 3.38$ and $\mathrm{I} 4.25 \mathrm{~h}$ and are best compared with the afternoon Pulfrich determinations given in Table 4.

6 November 1946. English Channel, station E I. Cubical submarine photometer. The weather was too rough for surface light-measurements. The water was isothermal to the bottom and the measurements with the cubical photometer also suggested homogeneous water. Consequently the discrepancy between the 0 and $25 \mathrm{~m}$ Pulfrich measurements and the other three are hard to understand. In default of a better explanation the discrepancy has been attributed to settling and the 0 and $25 \mathrm{~m}$ results rejected.

\section{Comparison of extinction coefficients determined near Plymouth in 1946 with the Pulfrich photometer and with submarine photometers}

Pulfrich measurements are made on samples from spot depths whereas the submarine photoelectric measurements are made over a range of depth. 
Both are subject not only to experimental error but to the inherent variability in transparency always likely in a vertical column in the sea. The only way to compare such measurements is to take some sort of mean figure obtained by each method over a range of depth within which optical properties were shown to be reasonably uniform. For the Pulfrich instrument this means the arithmetic mean of extinction coefficients obtained on several samples from depths within the range. For submarine photoelectric measurements where, say, four measurements of light intensity at different depths were made, these were bracketed two at a time to give six values for the extinction coefficient. The mean of these six values or 'brackets' is considered to be the best measure of the extinction coefficient of the layer in question. On some occasions the available measurements fall short of requirements.

TABLE 6. COMPARISON OF EXTINCTION COEFFICIENTS IN GREEN LIGHT $(530 \mathrm{~m} \mu)$ MEASURED WITH THE PULFRICH PHOTOMETER AND BY SUBMARINE PHOTOMETER ON 12 JULY 1946

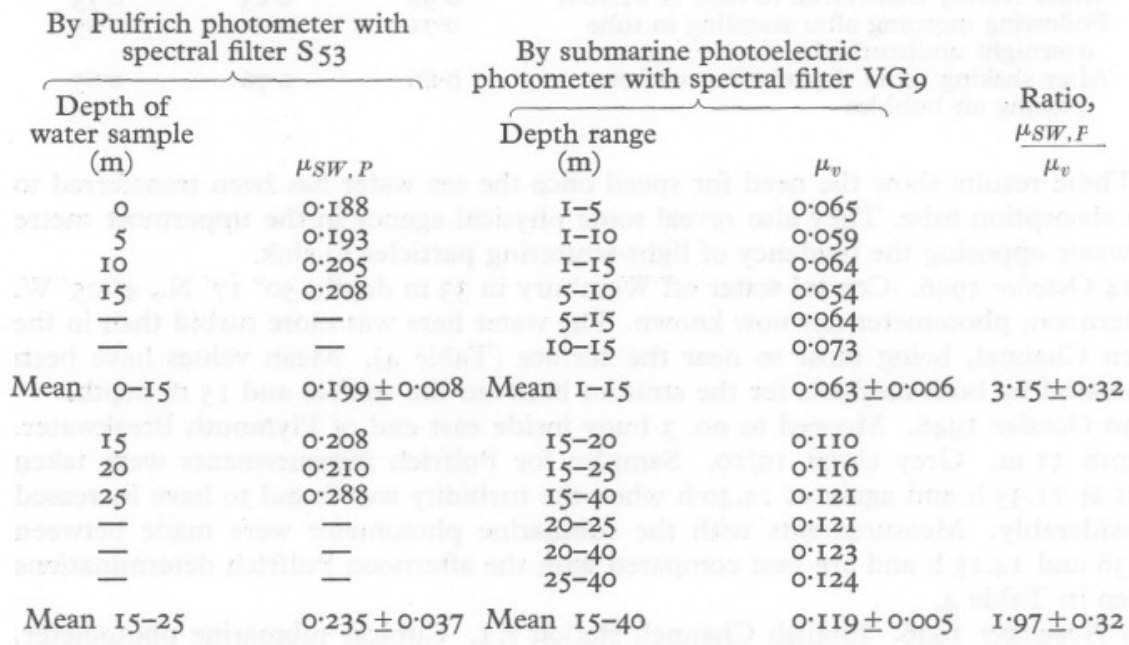

To illustrate the method all the observations on I2 July 1946 are set out in Table 6 with standard deviations. All the available data are summarized in Table 7. In the last column the ratios of extinction coefficients determined by the two methods are shown with standard deviations of the ratio when assessable. Although, due to the small samples of raw data, the statistical validity of these standard deviations cannot be rated high, it is considered that they show the order of magnitude of the variability inherent in the ratios. They are unsuitable for statistical analysis such as analysis of variance.

For the different colours the arithmetic means and the ranges of the ratios are collected in Table 8 . 
The ratios of extinction coefficients measured with the Pulfrich photometer to the coefficients measured by a submarine photoelectric photometer ranged between 2 and 6 for green light and between 2 and 5 for blue violet. The results for 26 August which included submarine measurements with five filter combinations show the decrease in ratios from green through yellow to red and are presented in a separate column. The variation amongst these

TABLE 7. COMPARISON OF EXTINCTION COEFFICIENTS MEASURED BY THE PULFRICH PHOTOMETER AND BY SUBMARINE PHOTOMETERS

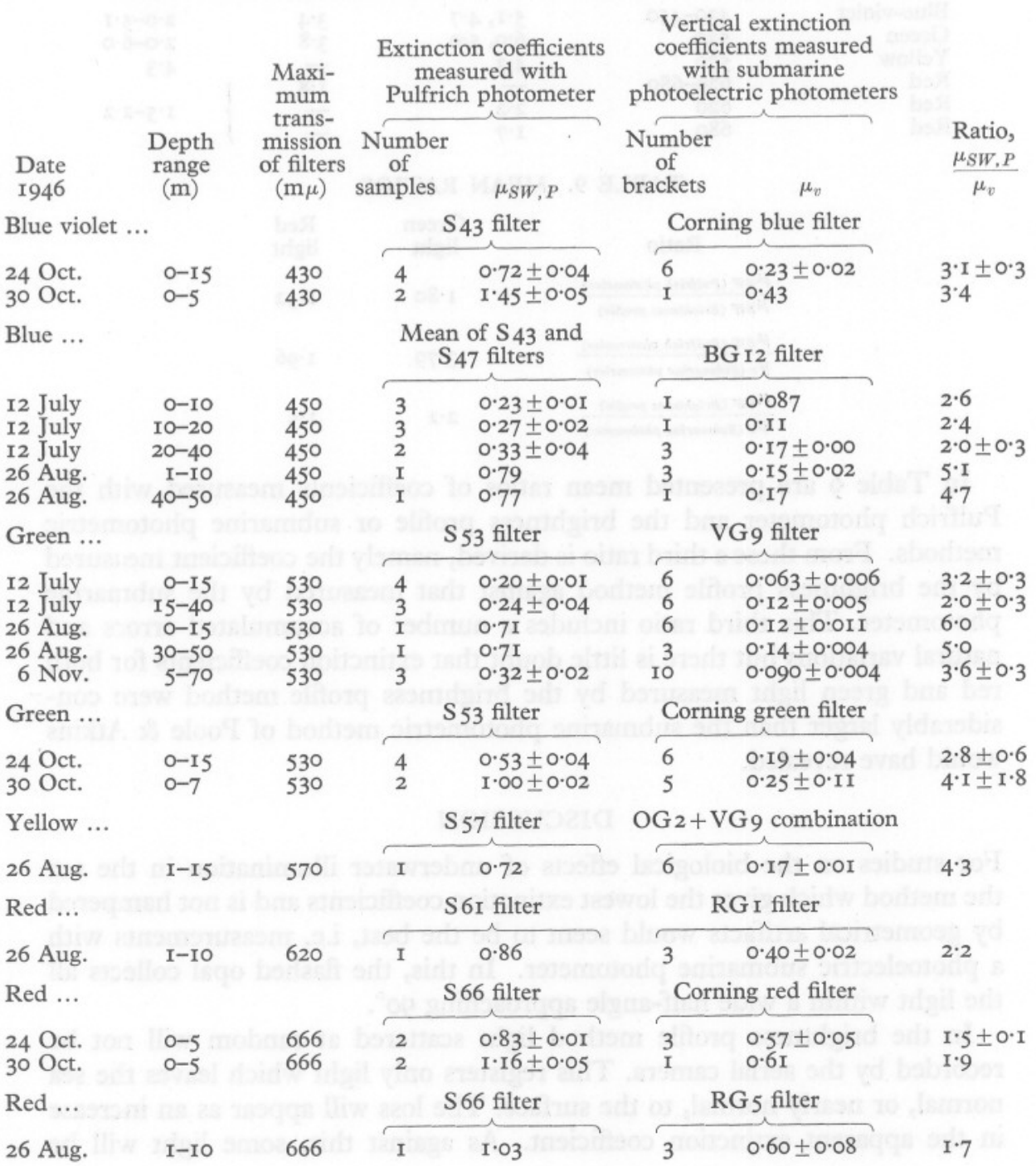


ratios much exceeds the standard deviation on any single ratio and unquestionably illustrates a fundamental property associated with the variable presence of scattering particles. With red light the much smaller absolute values of the ratio and the smaller range accord with this explanation.

TABLE 8. VARIATION WITH WAVE-LENGTH OF RATIOS OF EXTINCTION COEFFICIENTS MEASURED (a) WITH THE PULFRICH PHOTOMETER AND (b) WITH THE SUBMARINE PHOTOMETER

\begin{tabular}{|c|c|c|c|c|}
\hline Colour & $\begin{array}{l}\text { Wave-length } \\
\text { (m) }\end{array}$ & $\begin{array}{l}26 \text { August } 1946 \\
\text { only }\end{array}$ & $\begin{array}{l}\text { Mean of } \\
\text { all ratios }\end{array}$ & $\begin{array}{l}\text { Range of } \\
\text { ratios }\end{array}$ \\
\hline Blue-violet & $430-450$ & $5 \cdot I, 4 \cdot 7$ & $3 \cdot 4$ & $2 \cdot 0-5 \cdot 1$ \\
\hline Green & 530 & $6 \cdot 0,5 \cdot 0$ & $3 \cdot 8$ & $2 \cdot 0-6 \cdot 0$ \\
\hline Yellow & 570 & $4 \cdot 3$ & - & $4 \cdot 3$ \\
\hline Red & $620-680$ & - & $\mathrm{I} \cdot 8$ & \\
\hline Red & 620 & $2 \cdot 2$ & - & $I \cdot 5-2 \cdot 2$ \\
\hline Red & 680 & $I \cdot 7$ & - & \\
\hline
\end{tabular}

TABLE 9. MEAN RATIOS

$\begin{array}{lcc}\text { Ratio } & \begin{array}{c}\text { Green } \\ \text { light }\end{array} & \begin{array}{c}\text { Red } \\ \text { light }\end{array} \\ \frac{\mu_{S W} \text { (Pulfrich photometer) }}{\mu_{S W} \text { (Brightness profle) }} & \mathrm{I} \cdot 80 & \mathrm{I} \cdot 32 \\ \frac{\mu_{S W \text { (Pultrich photometer) }}}{\mu_{v \text { (Submarine photometer) }}} & 3.79 & \mathrm{I} \cdot 96 \\ \frac{\mu_{S W \text { (Brightness profle) }}}{\mu_{v \text { (Submarine photometer) }}} & 2.2 & \mathrm{I} \cdot 5\end{array}$

In Table 9 are presented mean ratios of coefficients measured with the Pulfrich photometer and the brightness profile or submarine photometric methods. From these a third ratio is derived, namely the coefficient measured by the brightness profile method against that measured by the submarine photometer. This third ratio includes a number of accumulated errors and natural variations but there is little doubt that extinction coefficients for both red and green light measured by the brightness profile method were considerably larger than the submarine photometric method of Poole \& Atkins would have revealed.

\section{DISCUSSION}

For studies on the biological effects of underwater illumination in the sea the method which gives the lowest extinction coefficients and is not hampered by geometrical artifacts would seem to be the best, i.e. measurements with a photoelectric submarine photometer. In this, the flashed opal collects all the light within a wide half-angle approaching $90^{\circ}$.

In the brightness profile method light scattered at random will not be recorded by the aerial camera. This registers only light which leaves the sea normal, or nearly normal, to the surface. The loss will appear as an increase in the apparent extinction coefficient. As against this, some light will be 
back-scattered before it reaches the sea bed. For this the length of path in water will be less than twice the depth, the effect being to decrease the apparent extinction coefficient. In coastal water of the English Channel it has been shown that the brightness profile method yields extinction coefficients greater than the submarine photometer by a factor of about $2 \cdot 2$ for green light and about $\mathrm{I} \cdot 5$ for red light.

In the Pulfrich photometer the light traverses the water once only so that there is no change in apparent extinction coefficient due to back scattering. The discrepancy with the submarine photometric method is even greater and is very variable, being much dependent on the quantity and nature of the scattering particles. The factor averages about 3.8 for green light and 2.0 for red light.

The conclusions from this investigation in no way invalidate Moore's brightness profile method for determining beach gradients, shown by internal evidence to be very well suited for the purpose for which he designed it.

Methods in which optical measurements are made on sea-water samples confined in tubes are still (1960) in common use. Though these methods may be internally consistent, a study of the geometry of the light paths through the instruments (cf. Appendix) is essential if results obtained with them are to be compared with others observed directly on unconfined water in the sea.

\section{SUMMARY}

Three methods of determining extinction coefficients of light in sea water have been compared: $(a)$ on water samples contained in a Pulfrich photometer, (b) from 'brightness profiles' determined by aerial photographic survey, and $(c)$ by photoelectric underwater measurements.

The ratios of extinction coefficients for green and red light as determined in 1945 by the Pulfrich photometer and by the brightness profile method are given in Table 3, columns 9 and ro. For green light the ratio is about $\mathrm{I} \cdot 8$ and for red light $\mathrm{I} \cdot 3$.

The departure from unity is attributed to the geometry within a confined tube and, within the Pulfrich measuring assembly, of light rays scattered forward by particles present in sea-water samples.

In the following year, I946, comparisons were made between the Pulfrich method and the submarine photometric method of Atkins \& Poole. The discrepancies were variable and even larger, the ratios averaging 3.8 for green light and $2 \cdot 0$ for red light.

The brightness profile and submarine photometric methods have not been directly compared, but, by comparing the two sets of determinations against the Pulfrich photometer, it would seem that extinction coefficients determined with the brightness profile method are about $2 \cdot 2$ times those determined by the submarine photometer in green light and about I.5 times in red light. 
Discrepancies in extinction coefficients of light in sea water as determined in a Pulfrich photometer with long absorption tubes compared with coefficients determined by other methods are explained in the Appendix as due to forward scattering, combined with internal and specular reflexion and the geometry of the measuring assembly of the instrument.

\section{REFERENCES}

Atkins, W. R. G. \& Poole, H. H., 1952. An experimental study of the scattering of light by natural waters. Proc. roy. Soc. B, Vol. I40, pp. 32 I-38.

COOPER, L. H. N. \& MILNE, A., I938. The ecology of the Tamar Estuary. II. Underwater illumination. F. mar. biol. Ass. U.K., Vol. 22, pp. 509-28.

I939. The ecology of the Tamar Estuary. V. Underwater illumination. Revision of data for red light. F. mar. biol. Ass. U.K., Vol. 23, pp. 39I-6.

JAMES, H. R. WITH BIRGE, E. A., 1938. A laboratory study of the absorption of light by lake waters. Trans. Wis. Acad. Sci. Arts Lett., Vol. 3I, ch. 2.

Kalle, K., 1938. Zum Probleme der Meereswasserfarbe. Ann. Hydrogr. marit. Meteorol., Berl., I938, pp. I-13.

MOORE, J. G., 1947. The determination of the depths and extinction coefficients of shallow water by air photography using colour filters. Phil. Trans. B, Vol. 240, pp. $163-217$.

\section{APPENDIX}

The effects on measurements of light extinction by natural waters of scattering and internal reflexion in long absorption tubes

Extinction coefficients for light on samples of sea water confined in metre-long tubes in a modified Pulfrich photometer have been found to be much greater than coefficients on similar water determined directly in the sea, either by photoelectric submarine photometers or by aerial photography of 'brightness profiles' by Moore (1947). An explanation, long elusive, was provided by the work of Atkins \& Poole (1952) on forward scattering.

In the Pulfrich photometer the beam of light may be somewhat divergent; again, in a natural water scattering may occur. Let us however consider the fate of a parallel beam of light scattered at the point $P$ in water contained in a clear glass tube (Fig. I).

Since the refractive index of glass is greater than that of water, total internal reflexion will never occur at the inner glass-water interface. Specular reflexion will take place, but will be very small unless the angle with the axis of the tube is very low.

Light scattered from the point $P$ at a high angle with the axis of the tube will pass right through the glass wall and be lost completely. As the angle with the horizontal decreases the critical angle will be passed; then all light will be totally reflected from the outer or glass-air surface back into the water through which it will take a zig-zag course due to successive internal reflexions from the outer wall. Although the total reflexion takes place at the glass-air interface, a simple exercise in geometrical optics will show that the critical angle in question is that of water against air, $\mu=\mathrm{I} \cdot 34=$ $\mathrm{I} / \sin 48^{\circ}$. The limiting angle with the horizontal is the complement of this angle: $42^{\circ}$.

Atkins \& Poole (1952) have established that much of the light that is scattered in sea water is scattered forward at an angle less than about $42-45^{\circ}$, i.e. little light will be completely lost from the tube. Such scattered light will repeatedly be internally reflected in the absorption tube and will finally approach the end-plate within a cone 
of half-angle $42^{\circ}$. Since the end-plate is at right angles to the axis of the tube, the half angle of the cone of light after emergence will be even greater than it had been in the tube, $\sin ^{-1} \sqrt{ }\left(\mu^{2}-\mathrm{I}\right)$ or $63^{\circ}$. Little forward scattered light has been lost for a suitable integrating instrument could measure it. In consequence forward scattering seemed not to be an adequate explanation of the observed discrepancies until $\mathrm{Dr} \mathrm{H}$. H. Poole, in conversation, pointed out the crucial importance of the geometry of the measuring assembly of the Pulfrich photometer as illustrated in Zeiss Directions for the Use of the Pulfrich Photometer (no date), fig. 8. From this it is seen that the arrangement of diaphragms in that photometer will restrict the light received through the spectral filter by the eye to that which has emerged from the absorption tube as an essentially parallel beam. The cone of scattered, internally and specularly reflected light will be intercepted by diaphragms and by the inner walls of the photometer housing. It will be lost just as effectively as though it had been scattered through the glass walls of the absorption tube.

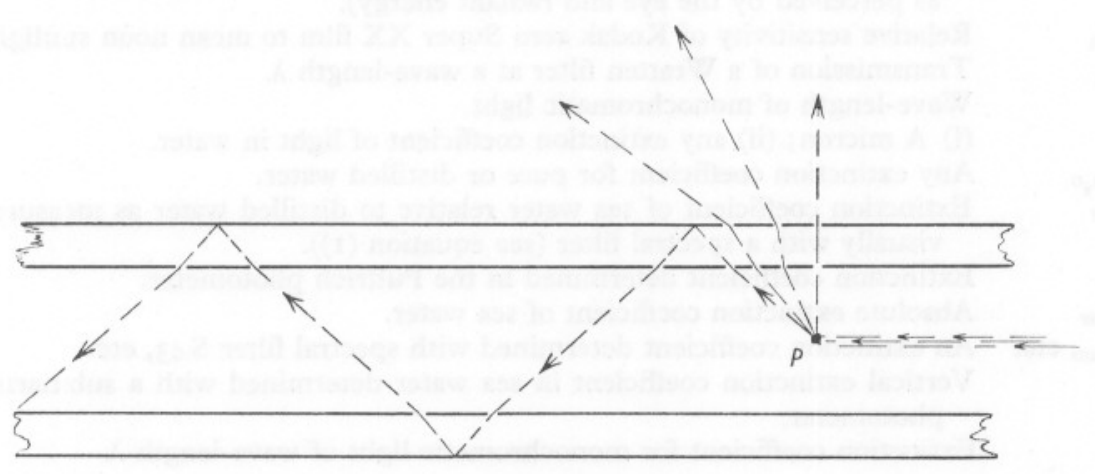

Fig. I

When the tubes, full of air or water, are viewed lengthways against a light source, strong reflexion from the walls is seen. Whether this is due to total reflexion from the outer glass-air surface or to specular reflexion from the inner glass-water surface has not been established nor does it matter.

This is no criticism of the Pulfrich photometer for the purpose for which it was designed-the measurement of colour; but it is dangerous to use it to measure phenomena which involve scattering of light, especially in long tubes.

Although measurements of absorption plus scattering made with the Pulfrich photometer adapted for use with long tubes do not represent events which occur in the sea, they are comparable with others made with the same apparatus and have value. Other workers have combined long absorption tubes with photometric devices. For these also it would be wise to examine the geometric path of light through the whole assembly to assess the effect of forward scattering.

For water of similar scattering power in shorter tubes, $25 \mathrm{~cm}$ long or less, as supplied by the makers, the effect should be much less. As against this, even in short tubes, turbid solutions with much scattering would be expected to show markedly higher extinction coefficients than they would if measured unconfined. 


\section{GLOSSARY OF SYMBOLS}

$a, b \quad$ Reading of right-hand Pulfrich photometer drum when right-hand drum is filled with distilled water/sea water.

$c_{\lambda} \quad$ Transmission of a spectral filter at a wave-length $\lambda$.

$D \quad$ A transmission measured with the photometer.

$g_{1}, g_{2} \quad$ Arbitrary readings of the left-hand drum of the Pulfrich photometer.

$\mathrm{H}_{2} \mathrm{O} \quad$ As a suffix, stands for distilled water or pure water in contrast to sea water $S W$.

$\mathrm{I}_{\mathrm{H}_{2} \mathrm{O}} \quad$ Intensity of luminous flux in distilled water.

$I_{S W} \quad$ Intensity of luminous flux in sea water.

$\mathscr{F}_{\lambda} \quad$ Relative energy of a light source at a given wave-length $\lambda$.

$l \quad$ Length of absorption tube.

$V_{\lambda} \quad$ Relative visibility at a wave-length $\lambda$ (relation between luminous sensation as perceived by the eye and radiant energy).

$Y_{\lambda} \quad$ Relative sensitivity of Kodak aero Super XX film to mean noon sunlight.

$Z_{\lambda} \quad$ Transmission of a Wratten filter at a wave-length $\lambda$.

$\lambda \quad$ Wave-length of monochromatic light.

$\mu \quad$ (i) A micron; (ii) any extinction coefficient of light in water.

$\mu_{\mathrm{H}_{2} \mathrm{O}} \quad$ Any extinction coefficient for pure or distilled water.

$\mu_{M} \quad$ Extinction coefficient of sea water relative to distilled water as measured visually with a spectral filter (see equation (I)).

$\mu_{P} \quad$ Extinction coefficient determined in the Pulfrich photometer.

$\mu_{S W} \quad$ Absolute extinction coefficient of sea water.

$\mu_{\mathrm{s} 43}$, etc. An extinction coefficient determined with spectral filter $\mathrm{S}_{43}$, etc.

$\mu_{v} \quad$ Vertical extinction coefficient in sea water determined with a submarine photometer.

$\mu_{\lambda} \quad$ Extinction coefficient for monochromatic light of wave-length $\lambda$. 